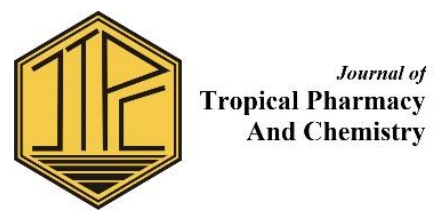

\title{
ANTIDIABETIC ACTIVITIES OF BROCCOLI EXTRACTS (Brassica oleracea L.var italica) ON MICE INDUCED STREPTOZOTOCIN-NICOTINAMIDE
}

\author{
Heni Lutfiyati ${ }^{1 * *}$, Fitriana Yuliastuti², Imron Wahyu Hidayat ${ }^{2}$, Prasojo Pribadi², \\ Sodiq Kamal ${ }^{3}$ \\ ${ }^{1}$ Pharmacy Technician Diploma Program, Faculty of Health Sciences, \\ Universitas Muhammadiyah Magelang, Indonesia \\ ${ }^{2}$ Department of Pharmacy, Faculty of Health Sciences, \\ Universitas Muhammadiyah Magelang, Indonesia \\ ${ }^{3}$ Department of Nursing, Faculty of Health Sciences, \\ Universitas Muhammadiyah Magelang, Indonesia \\ *Corresponding Author: henilutfiyati@ummgl.ac.id
}

\begin{abstract}
Several plant species have been used for the treatment of diabetes. Research on plants that can be used to treat diabetes such as Cinnamomum cassia and Cinnamomum zeylanicum, Piper sarmentosum Roxb, Nelumbo nucifera, Ceiba petandra, Memecylon malabaricum. Broccoli (Brassica oleracea L var italics) is a flower of vegetables like cabbage plants. Broccoli juice is made capable of direct and indirect effects on the reduction of blood LDL; the indirect effect is by repairing pancreatic beta cells and increasing insulin sensitivity. The purpose of this study was to determine whether broccoli has activity as antidiabetic. The subjects consisted of 15 mice induced with nicotinamide $70 \mathrm{mg} / \mathrm{kg} \mathrm{BW}$ and Stz $150 \mathrm{mg} / \mathrm{kg}$ BW. Diabetic mice were divided into the positive control group (glibenclamide), negative control group (CMC Na) and three treatment groups. The test material is broccoli extract dose $75 \mathrm{mg} / \mathrm{kg} \mathrm{BW}, 150 \mathrm{mg} / \mathrm{kg} \mathrm{BW}$ and $300 \mathrm{mg} / \mathrm{kg} \mathrm{BW}$ given peroral for 14 days. Anova test results showed that there was a significant difference in the average percentage of decreased blood glucose levels in all treatments. The result of Post Hock Tukey HSD test with a 95\% confidence level showed a significant difference in the negative control group compared with positive control group and extract $300 \mathrm{mg} / \mathrm{kg} \mathrm{BW}$. This result shows that positive control group and extracts $300 \mathrm{mg} / \mathrm{kg}$ body weight have an activity to decrease blood glucose level.
\end{abstract}

Keywords: antidiabetic activities, broccoli extract, streptozotocin-nicotinamide

Submitted on: 10 November 2018 Accepted on: 27 December 2018

DOI: https://doi.org/10.25026/jtpc.v4i4.203 


\section{INTRODUCTION}

In developed and developing countries the current treatment trend is back to nature, this is driven by the high side effects of chemical drugs that encourage the search for natural materials that are beneficial in medicine [1]. Traditional medicine side effects are relatively less compared to chemical drugs [2]. Several plant species have been used for the treatment of diabetes. Research on plants that can be used to treat diabetes in Asia-Pacific, for example, Cinnamomum cassia and Cinnamomum zeylanicum species, local names cinnamon [3]. Piper sarmentosum Roxb in Malaysia and southern Thailand [4]. Nelumbo nucifera, the local name of Indian lotus [5]. in Philippines Ceiba petandra stem extract with the local name Kapuk Randu [6], in Malaysian leaf extract (Memecylon malabaricum) is known to be used for diabetes medicine [7] and many other species can be used to treat diabetes in many ways.

Broccoli (Brassica oleracea L var italica) is a flower from vegetable plants like cabbage. Broccoli made with juice can provide a direct and indirect effect on the decrease in blood LDL. The direct effect is to prevent oxidase and repair weak so that LDL was not formed while the indirect effect is to repair pancreatic beta cells and increase insulin sensitivity. The glucose metabolism is good, and the blood glucose level returns to stable so that abnormal fat and protein metabolism does not occur due to LDL in the blood decline [8]. In the study [9] the results showed that giving Broccoli Sprout Powder in humans at a dose of 10 grams for four weeks could reduce $19.3 \%$ fasting blood glucose levels

Research [10] Sprague-Dawley (SD) rats type 2 diabetes mellitus which was induced streptozocin dose $(35 \mathrm{mg} / \mathrm{kg}$ BW) treated with Brassica oleracea var. Italica extracts with a dose of 200, 400 and $800 \mathrm{mg} / \mathrm{kg}$ body weight for 28 days. His results showed that the ethanol extract of Brassica oleracea extract had potential antidiabetic activity. So Brassica oleracea can be used to control hyperglycemia [11] in 11 prediabetes women with overweight and obesity nutritional status and fasting blood glucose levels between 100-125 $\mathrm{mg} / \mathrm{dl}$ given $140 \mathrm{~g}$ steamed broccoli for four weeks and the results can reduce glucose levels blood significantly. Diabetes mellitus is closely related to pancreatic beta cell dysfunction and insulin resistance [12]. Damage to pancreatic beta cells can be caused partly due to genetic factors.

\section{MATERIALS METHOD}

\section{Tools and materials}

The tools used in this study are analytical balance sheets, a set of safety equipment, rotary evaporator, glassware, water bath, insulin syringe, Gluco Dr test, mouse cage, oral syringe.

The test material used was broccoli obtained from Ngablak Village, Magelang, the ingredients for making broccoli ethanol extract ethanol 96\%, silica, and filter paper. The materials used to induce type $2 \mathrm{DM}$ mice were Streptozotocin and Nicotinamide (Sigma) extract suspensions and controls namely $0.5 \% \mathrm{CMC} \mathrm{Na}$ which was made by weighing $500 \mathrm{mg} \mathrm{CMC} \mathrm{Na}$ then dissolved in $100 \mathrm{ml}$ hot water, positive control with glibenclamide. Measuring blood glucose levels with Gluco sticks. The test animals used male Balb-c mice aged three months with a weight of 20-30 g obtained from the Experimental Animal Services Unit (UPHP), Integrated Research and Testing Laboratory (LPPT), Gadjah Mada University, Yogyakarta.

\section{Material Preparation}

The sample used was fresh broccoli obtained from Ngablak Village, Magelang, and then conducted Determination at the Biology Laboratory of Ahmad Dahlan 
University, Yogyakarta. The sample selection begins with fresh sortation material, then the broccoli washed with running water, then chopped and dried in the oven, and dried broccoli was obtained as much as $605.4 \mathrm{~g}$. After that, the dry simplicia is made a powder with blender and sifted as much as $312 \mathrm{~g}$ of simplicia powder.

\section{Preparation of broccoli extract}

Preparation for broccoli extract using maceration method with $96 \%$ ethanol. $300 \mathrm{~g}$ of broccoli powder macerated with $96 \%$ ethanol as much as 1.5 liters for 24 hours. The extract obtained was evaporated above the water bath. The pulp from maceration was generated twice as much. Each uses $750 \mathrm{~mL}$ ethanol.

\section{Extract identification test}

The identification of broccoli extract aims to determine the content of secondary metabolites contained in broccoli extract. Phytochemical screening of broccoli (Brassica oleracea L var italica) includes tests of alkaloids, saponins, tannins, flavonoids, terpenoids, and steroids.

\section{Preparation}

The preparation of the test was carried out to facilitate. Assay to the test animals for each group obtained the appropriate weight for both the dosage given and the volume of the administration. The CMC Na $0.5 \%$ solution was made for negative control and as a suspending, glibenclamide suspension (positive control), extract suspension dose $75 \mathrm{mg} / \mathrm{kg}$ BW, $150 \mathrm{mg} / \mathrm{kg} \mathrm{BW}$ and $300 \mathrm{mg} / \mathrm{kg} \mathrm{BW}$.

\section{Testing the antidiabetic activity of mice induced streptozotocin and nicotinamide}

The test animals used were mice aged three months with a body weight of 20-30 grams, obtained from UPHP. In order for variations during the study to be minimized, male mice are used. The treatment was carried out for 14 days mice were divided into five groups; each group consisted of 3 mice [13] and grouping as in table 1 .

\section{Induction}

Induction of mice using nicotinamide $70 \mathrm{mg} / \mathrm{mg} \mathrm{BW}$ and STZ 150 $\mathrm{mg} / \mathrm{kg} \mathrm{BW}$. Mice with blood glucose levels above $100 \mathrm{mg} / \mathrm{dl}$ are considered to have diabetes mellitus

\section{Procedure for determining blood glucose levels}

Blood samples during treatment were determined for blood glucose levels on day 0, and 14. [14] Day 0 blood glucose level measurement was the measurement of blood glucose levels of mice before getting treatment and the 14th day was to see the blood glucose levels of mice after receiving broccoli extract for 14 days. Taking blood samples is done in a state of mice that have been fasted for 8 to 10 hours

\section{Analyze data}

The blood glucose level values of all groups are presented in the form of tables and graphs, then statistically analyzed using One Way ANOVA variance analysis with $95 \%$ confidence level followed by Tukey HSD Post Hock

\section{RESULT AND DISCUSSION}

The sample used in this study was fresh broccoli from farmers in the village of Ngablak, Magelang Regency. Sample selection begins with the wet sorting of 20 $\mathrm{kg}$ of broccoli that is suitable for use 5,208 grams. Broccoli is washed with running water and then chopped and dried in the oven. Then the dried leaves were obtained as much as 605.4 grams. After that, the dry simplicia was made a powder with blended and sieved obtained as much as 312 grams of Simplicia powder. 
Preparation of broccoli extract using maceration method with ethanol $96 \%, 312$ grams of broccoli powder macerated with $96 \%$ ethanol as much as 1.5 liters for 24 hours. The extract obtained was evaporated above the water bath. The pulp from maceration is generated twice as much. Each uses $750 \mathrm{ml}$ ethanol. The result of maceration is 63.14 grams of concentrated extract. The yield of broccoli extract obtained is $20.18 \%$

The results of phytochemical screening of Broccoli extract (Brassica oleracea L var italics) contain alkaloids, tannins, flavonoids, saponins and steroids Alkaloids in the health field have pharmacological activities as antidiabetic and antihypertensive [13-16]. Alkaloids also have activities as anti-microbial and anti-parasitic [16]. Saponin has pharmacological activity as an antibacterial [17], antidiabetic [6], reducing cholesterol levels, anti-coagulant, anti-carcinogen, hepatoprotective, immunomodulatory, antidiabetic, neuroprotective, anti-inflammatory and anti-oxidant [18]. Tanin has activity as an antioxidant and is used as cardioprotective, anti-carcinogenic, anti-inflammatory and anti-mutagenic. Tanin can also increase glucose uptake and inhibit adipogenesis so that it is potentially used to treat Diabetes Mellitus [19]. Broccoli ethanol extract was shown to be able to control blood glucose levels in type $2 \mathrm{DM}$ models induced with Streptozotocin (STZ) [10, 20]. Flavonoids have activities as anti-oxidants, antibacterial, anti-diabetes mellitus [21] and steroids have antibacterial activity [22].

Test animals Balb / C mice aged 23 months induced with nicotinamide solution $70 \mathrm{mg} / \mathrm{kg}$ body weight in normal saline intraperitoneally, 15 minutes later mice induced again with streptozotocin $120 \mathrm{mg} / \mathrm{kg} \mathrm{BW}$ in the citrate buffer. Measuring blood glucose levels on the 7 th day after induction and seeing an increase in blood glucose levels than compared with blood glucose levels before induction. Mice used in this study that had blood glucose levels $>100 \mathrm{mg} / \mathrm{dl}$. Mice induced with streptozotocin which were previously given nicotinamide experienced a decrease in pancreatic levels similar to type $2 \mathrm{DM}$.

Blood glucose levels were measured after mice fasted for 8-10 hours. Blood glucose measurements of mice were carried out on days 0 and 14 after administration of ethanol extract. The following are the data on the average percentage reduction in blood glucose levels as shown in table 2 .

Table 1. Test animal group

\begin{tabular}{ccccc}
\hline Negative Control & Positive Control & Group I & Group II & Group III \\
\hline CMC Na 0.5\% for & Glibenclamide 4.5 & At dose of Broccoli & At dose of Broccoli & At dose of Broccoli \\
14 days & mg/kg BW for 14 & Extract 75 mg/kg & Extract 150 mg/Kg & Extract 300 mg/Kg \\
& days & BW for 14 days & BW for 14 days & BW for 14 days \\
\hline
\end{tabular}

Table 2. The average percentage of decrease in blood glucose levels

\begin{tabular}{lc}
\hline \multicolumn{1}{c}{ Group } & the decrease in blood glucose (\%) \\
\hline CMC Na 0.5\% & $13.6 \pm 6.9$ \\
Glibenclamide $4.5 \mathrm{mg} / \mathrm{kg} \mathrm{BW}$ & $61.6 \pm 4.8$ \\
Broccoli Extract $75 \mathrm{mg} / \mathrm{kg} \mathrm{BW}$ & $7.8 \pm 4.7$ \\
Broccoli Extract $150 \mathrm{mg} / \mathrm{kg} \mathrm{BW}$ & $16.5 \pm 2.0$ \\
Broccoli Extract $300 \mathrm{mg} / \mathrm{kg} \mathrm{BW}$ & $38.1 \pm 8.6$ \\
\hline
\end{tabular}


Table 3. ANOVA Test result

\begin{tabular}{|c|c|c|c|c|c|}
\hline & Sum of Squares & df & Mean Square & $\mathrm{F}$ & Sig. \\
\hline Between Groups & 5939.067 & 4 & 1484.767 & 36.691 & .000 \\
\hline Within Groups & 404.667 & 10 & 40.467 & & \\
\hline Total & 6343.733 & 14 & & & \\
\hline
\end{tabular}

Table 4. Tukey HSD Post Hoc Test Results

\begin{tabular}{llll}
\hline & Treatment Group & Sig & Conclusion \\
\hline Positive & Negative Control & 0.000 & Significant \\
Control & Extract $75 \mathrm{mg} / \mathrm{kg}$ weight & 0.000 & Significant \\
& Extract $150 \mathrm{mg} / \mathrm{kg}$ weight & 0.000 & Significant \\
& Extract $300 \mathrm{mg} / \mathrm{kg}$ weight & 0.007 & Not Significant \\
\hline Negative & Positif Control & 0.000 & Significant \\
Control & Extract $75 \mathrm{mg} / \mathrm{kg}$ weight & 0.775 & Not Significant \\
& Extract $150 \mathrm{mg} / \mathrm{kg}$ weight & 0.975 & Not Significant \\
& Extract $300 \mathrm{mg} / \mathrm{kg}$ weight & 0.006 & Significant \\
\hline
\end{tabular}

The Kolmogorov test data results are normally distributed with a significance value of 0.570 , indicating that the overall data was usually distributed. Analysis of homogeneity test was carried out to test whether there was a similarity in the percentage of blood glucose reduction between the five treatment groups. It was concluded that the research data was homogeneous. Based on the normality and homogeneity test, the percentage of decrease in blood glucose levels obtained is known to be normally distributed and homogeneous, then it meets the requirements for testing using Anova. Anova test results are shown in table 3.

The results of the ANOVA test showed that there was a significant difference in the average percentage of decrease in blood glucose levels between all treatment groups. After the ANOVA Test was carried out, followed by the Tukey HSD Post Hoc Test with output results as listed in Table 4.

Tukey HSD was used to determine differences between groups and the Tukey HSD test results at the $95 \%$ confidence level showed significant differences in the positive group when compared with the negative control group; the treatment group dose was $75 \mathrm{mg} / \mathrm{kg} \mathrm{BW}$ and $150 \mathrm{mg} / \mathrm{kg}$ BW. The positive control group showed significant differences in the Tukey test for negative controls. The presence of these significant differences indicates that glibenclamide (positive control) has an antidiabetic effect. Based on the Tukey HSD Post Hoc test above, it is also seen that in the negative control group showed a significant difference with the $300 \mathrm{mg}$ dose group; it can be concluded that the dose has effectiveness comparable to glibenclamide (positive control).

Research [10] Sprague-Dawley rats that were induced by low-dose STZ (35 $\mathrm{mg} / \mathrm{kg} \mathrm{BW}$ ) and high-fat diets were given broccoli extract in the form of $200 \mathrm{mg} / \mathrm{kg}$ body weight, $400 \mathrm{mg} / \mathrm{kg}$ body weight and $800 \mathrm{mg} / \mathrm{kg}$ body weight during 28 days and as a positive control Metformin 250 $\mathrm{mg} / \mathrm{kg}$ BW was used. The measurement results after the 28th day showed that in the three groups given metformin dose of 200 $\mathrm{mg} / \mathrm{kg} \mathrm{BW}, 400 \mathrm{mg} / \mathrm{kg} \mathrm{BW}$ and $800 \mathrm{mg} / \mathrm{kg}$ 
$\mathrm{Bb}$ there was a decrease in fasting blood glucose.

Research [20] in mice induced with STZ $(55 \mathrm{mg} / \mathrm{kg}$ body weight in citrate $0.1 \mathrm{M})$ given Broccoli extract $100 \mathrm{mg} / \mathrm{kg}$ body weight, $200 \mathrm{mg} / \mathrm{kg}$ body weight for 21 days showed that diabetic rats experienced weight loss and decreased blood glucose levels.

Broccoli is a natural anti-oxidant that can be used as a diet supplement to minimize oxidative stress to prevent the risk of degenerative diseases. Broccoli also has an activity to reduce cholesterol levels in the blood directly by preventing fat oxidation and improving fat metabolism while indirectly by repairing pancreatic beta cells and increasing insulin sensitivity [23].

\section{CONCLUSION}

Ethanol extract of broccoli has antidiabetic activity in mice induced with nicotinamide $70 \mathrm{mg} / \mathrm{kg}$ body weight and Streptozotocin $150 \mathrm{mg} / \mathrm{kg}$ body weight

\section{ACKNOWLEDGMENT}

Thank you to the Ministry of Research, Technology and Higher Education, Head and Laboratory of Muhammadiyah Magelang and Head of the Basic Natural Sciences Laboratory of the University of Muhammadiyah Magelang.

\section{REFERENCES}

[1] Pramono, S., 2002. Kontribusi bahan obat alam dalam mengatasi krisis bahan obat di Indonesia. Jurnal Bahan Alam Indonesia. 1. 18-20.

[2] Sari, L. O. R. K., 2012. Pemanfaatan obat tradisional dengan pertimbangan manfaat dan keamanannya. Pharmaceutical Sciences and Research (PSR). 3. 1-7.

[3] Verspohl, E. J., Bauer, K., Neddermann, E., 2005. Antidiabetic effect of Cinnamomum cassia and Cinnamomum zeylanicum in vivo and in vitro. Phytotherapy Research: An International Journal Devoted to Pharmacological and Toxicological Evaluation of Natural Product Derivatives. 19. 203-206.

[4] Peungvicha, P., Thirawarapan, S. S., Temsiririrkkul, R., Watanabe, H., Prasain, J. K., Kadota, S., 1998. Hypoglycemic effect of the water extract of Piper sarmentosum in rats. Journal of ethnopharmacology. 60. 27-32.

[5] Mukherjee, P. K., Saha, K., Pal, M., Saha, B., 1997. Effect of Nelumbo nucifera rhizome extract on blood sugar level in rats. Journal of ethnopharmacology. 58. 207-213.

[6] Elekofehinti, O. O., 2015. Saponins: Anti-diabetic principles from medicinal plants-A review. Pathophysiology. 22. 95-103.

[7] Amalraj, T., Ignacimuthu, S., 1998. Evaluation of the hypoglycaemic effect of Memecylon umbellatum in normal and alloxan diabetic mice. Journal of ethnopharmacology. 62. 247-250.

[8] Setyoadi, S., Utami, Y. W., Yuliatun, L., 2014. Jus brokoli menurunkan kadar low density lipoprotein darah pada tikus model diabetes melitus. Jurnal Kedokteran Brawijaya. 28. 26-29.

[9] Bahadoran, Z., Tohidi, M., Nazeri, P., Mehran, M., Azizi, F., Mirmiran, P., 2012. Effect of broccoli sprouts on insulin resistance in type 2 diabetic patients: a randomized double-blind clinical trial. International journal of food sciences and nutrition. 63. 767-771.

[10] Shah, M. A., Sarker, M., Gousuddin, M., 2016. Antidiabetic potential of Brassica Oleracea Var. Italica in type 2 diabetic sprague dawley (sd) rats. Int J Pharmacogn Phytochem Res. 8. 462-469. 
[11] Wulandari, N. E., Wirawanni, Y., 2014. Pengaruh Pemberian Brokoli Kukus (Brassica Oleracea) Terhadap Kadar Glukosa Darah Puasa Wanita Prediabetes. Diponegoro University.

[12] Kaneto, H., Kajimoto, Y., Miyagawa, J.-i., Matsuoka, T.-a., Fujitani, Y., Umayahara, Y., Hanafusa, T., Matsuzawa, Y., Yamasaki, Y., Hori, M., 1999. Beneficial effects of antioxidants in diabetes: possible protection of pancreatic beta-cells against glucose toxicity. Diabetes. 48. 2398-2406.

[13] Indrawati, S., Yuliet, Y., Ihwan, I., 2015. Efek Antidiabetes Ekstrak Air Kulit Buah Pisang Ambon (Musa paradisiaca L.) terhadap Mencit (Mus musculus) Model Hiperglikemia. Jurnal Farmasi Galenika (Galenika Journal of Pharmacy). 1. 133-140.

[14] Perlitasari, Y., Prasetyo, D. H., 2016. Pengaruh pemberian ekstrak herba anting-anting (Acalypha indica) terhadap kadar malondialdehyde (MDA) pada mencit Balb/C induksi streptozotocin. Bioteknologi. 13. 8390.

[15] Sangi, M., Runtuwene, M. R., Simbala, H. E., Makang, V. M., 2008. Analisis fitokimia tumbuhan obat di Kabupaten Minahasa Utara. Chemistry Progress. 1. 47-53.

[16] Aniszewki, T., 2007. Alkaloidsecrets of life. Belanda: Elsevier.
[17] Bahadoran, Z., Mirmiran, P., Hosseinpanah, F., Hedayati, M., Hosseinpour-Niazi, S., Azizi, F., 2011. Broccoli sprouts reduce oxidative stress in type 2 diabetes: a randomized double-blind clinical trial. European journal of clinical nutrition. 65. 972.

[18] Rao, A., Gurfinkel, D., 2000. The bioactivity of saponins: triterpenoid and steroidal glycosides. Drug metabolism and drug interactions. 17. 211-236.

[19] Kumari, M., Jain, S., 2012. Tannins: An antinutrient with positive effect to manage diabetes. Research Journal of Recent Sciences. 2277. 2502.

[20] Patel, V., Sharma, V., 2014. Effect of Brassica oleracea Extracts on Blood Glucose and Antioxidant Profile in Streptozotocin Induced Diabetic Rats. J. Med. Pharm. Innov. 1. 4-9.

[21] Grassi, D., Desideri, G., Ferri, C., 2010. Flavonoids: antioxidants against atherosclerosis. Nutrients. 2. 889-902.

[22] Epand, R. F., Savage, P. B., Epand, R. M., 2007. Bacterial lipid composition and the antimicrobial efficacy of cationic steroid compounds (Ceragenins). Biochimica et Biophysica Acta (BBA)-Biomembranes. 1768. 25002509.

[23] Fatharanni, M. O., Anggraini, D. I., 2017. Efektivitas Brokoli (Brassica Oleracea var. Italica) dalam Menurunkan Kadar Kolesterol Total pada Penderita Obesitas. Jurnal Majority. 6. 64-70. 